Gut, 1973, 14, 374-375

\title{
Discordance for childhood coeliac disease in monozygotic twins
}

\author{
J. A. WALKER-SMITH ${ }^{1}$
}

From the Department of Gastroenterology, Royal Alexandra Hospital for Children, Camperdown, NSW, Australia

SUMMARY Discordance for childhood coeliac disease in monozygotic twin boys is reported. The diagnosis of coeliac disease in the second-born twin was established by demonstration of a flat small intestinal mucosa on biopsy and a clinical response to a gluten-free diet. The first-born twin had a normal small intestinal mucosa. Phenotypic, genotypic, and dermatoglyphic observations as well as gross observation of the placenta and membranes provided strong evidence that these twin boys were monozygotic.

It is now well known that coeliac disease may occur in several members of the one family (Thompson, 1951; Boyer and Anderson, 1956; Carter, Sheldon, and Walker, 1959). However, the mode of inheritance of coeliac disease has not yet been generally agreed to. There are a number of reports of twins who also were said to have coeliac disease in childhood (Fanconi, 1928; Haas, 1932; Collishaw, 1940; MacDonald, Dobbins, and Rubin, 1965) but in only one of these reports is small intestinal biopsy used to establish the diagnosis (MacDonald et al, 1965 ) and in none of these reports is the zygosity of the twins clearly established. Discordance for adult coeliac disease has been documented in one monozygotic twin pair (Hoffman, Wollaeger, and Greenberg, 1966) but there is no similar report in children, where the diagnosis of coeliac disease has been established by biopsy, although Carter et al (1959) did report discordance for childhood coeliac disease in twins, but their diagnosis was not based on small intestinal biopsy.

The purpose of this paper is to report discordance for coeliac disease in a monozygotic twin pair, where the zygosity of the twins has been documented by dermatoglyphic and blood group studies, and where the diagnosis of coeliac disease has been established by the demonstration of a flat small intestinal mucosa and a clinical response to a gluten-free diet.

Two pairs of twins have been encountered from 117 consecutive cases of coeliac disease seen at the

${ }^{1}$ Address for reprints: Dr J. A. Walker-Smith, Department of Child Health, St Bartholomew's Hospital, West Smithfield, London EC1. Received for publication 1 February 1973.
Royal Alexandra Hospital for Children from 1 January 1966 to 1 November 1972. The first pair of twins encountered were dizygotic and one was established to have coeliac disease and the other child had a normal small intestinal mucosa on biopsy. The second pair of twins were monozygotic and are the subject of this report.

\section{Case History}

The first born of the male twins reported had a birth weight of $2.6 \mathrm{~kg}$ and a length of $47 \mathrm{~cm}$, the second having a birth weight of $2 \cdot 1 \mathrm{~kg}$ and a length of $46.5 \mathrm{~cm}$. They were three weeks premature and examination of the placenta and membranes indicated a uniovular twin pregnancy. Both twins were subsequently well, until the second twin was brought to the Casualty Department of the Royal Alexandra Hospital for Children at the age of 11 months with a history of loose motions for three months and vomiting of solids for one month. He was developmentally one month behind his twin brother.

Both twins had been exposed to gluten at the age of 6 weeks. Twin II had the typical flat small intestinal mucosa characteristic of coeliac disease on biopsy. He was started on a gluten-free diet and subsequently he has gained weight and he is now clinically symptom free. Small intestinal biopsy was performed on his brother, although he did not have any symptoms of coeliac disease, because of the previous reports of both members of a pair of twins having coeliac disease. His small intestinal mucosa was normal on biopsy. 


\section{Zygosity studies}

On physical examination the twins appeared to be identical. Dermatoglyphic patterns were performed in both children and total ridge counts estimated. In twin I the total ridge count was 142, and in twin II it was 137. The difference in the total ridge count between the two was therefore 5. On consulting tables of probability of a like-sexed twin pair being dizygotic according to differences in total finger ridge count (Lamy, Frézal, De Grouchy, and Kelley, 1957) it appeared likely that the twins were monozygotic. An identical difference of 5 in the ridge count was found by Hoffman, Wollaeger, and Greenberg (1966) in their report of adult monozygotic twins. Both twins were blood group $O$, and, using specific antisera, genotypic identity was established for group c, D, Jk ${ }^{\mathbf{a}}, \mathrm{Jk}^{\mathbf{b}}, \mathbf{M}, \mathrm{N}, \mathrm{S}, \mathrm{s}$, and $P$.

Thus taking into account the placental findings and the above dermatoglyphic and blood group findings there is strong evidence that the twins reported here were monozygotic.

\section{Discussion}

This report establishes for the first time, on the basis of a diagnosis of coeliac disease resting on a flat small intestinal mucosa and a clinical response to a gluten-free diet, the fact that there is discordance for childhood coeliac disease in monozygotic twins.

This observation is not surprising in the light of the report of Hoffman et al (1966) as coeliac disease, whether it occurs in children or adults, is now believed to be one and the same disease. It supports the view that coeliac disease is unlikely to be due to a genetically determined enzyme deficiency (Booth,
1970), and argues against the hypothesis of MacDonald et al (1965) that coeliac disease is inherited as a dominant gene with incomplete penetrance. McCrae's (1970) hypothesis that the genetic component of coeliac disease is a susceptibility to damage by a number of environmental factors, the susceptibility being inherited as a polygenic variation, seems a much better way to explain the familial incidence of this disease.

My thanks are due to Mr S. Purvis-Smith of the Children's Medical Research Foundation, Royal Alexandra Hospital for Children, who performed the dermatoglyphic studies, and to the Sydney Red Cross Transfusion Service for the blood group observations.

References

Booth, C. C. (1970). The enterocyte in coeliac disease. Brit. med. J., 4, 14-17.

Boyer, P. H., and Andersen, D. (1956). A genetic study of celiac disease; incidence of celiac disease, gastrointestinal disorders, and diabetes in pedigrees of children with celiac disease. Amer. J. Dis. Child., 91, 131-137.

Carter, C., Sheldon, W., and Walker, C. (1959). The inheritance of coeliac disease. Ann. hum. Genet., 23, 266-278.

Collishaw, D. (1940). Coeliac disease in twins. Brit. med. J., 2, 904.

Fanconi, G. (1928). Der intestinal Infantilismus und ähnliche Formen der chronischen Verdauungstorung, pp. 120-122. Karger, Berlin.

Haas, S. V. (1932). Celiac disease, J. Amer, med. Ass, 99, 448-452.

Hoffman, H. N., Wollaeger, E. E., and Greenberg, E. (1966). Discordance for nontropical sprue (adult celiac disease) in a monozygotic twin pair. Gastroenterology, 51, 36-42.

Lamy, M., Frézal, J., De Grouchy, J., and Kelley, J. (1957). Le nombre de dermatologyphes dans un échantillon de jumeaux. Ann. hum. Genet., 21, 374-396.

McCrae, W. M. (1970). The inheritance of coeliac disease. In Coeliac Disease, edited by C. C. Booth and R. H. Dowling, pp. 55-63. Churchill Livingstone, London.

MacDonald, W. C., Dobbins, W. O., and Rubin, C. E. (1965). Studies on the familial nature of celiac sprue using biopsy of the small intestine. New Engl. J. Med., 272, 448-456.

Thompson, M. W. (1951). Heredity, maternal age, and birth order in the etiology of celiac disease. Amer. J. hum. Genet., 3, 159-166. 